\author{
Г. В. Алексеев [G. V. Alekseev] \\ O. А. Егорова [O. A. Egorova] \\ A. Г. Лey [A. G. Leu]
}

\title{
ЭФФЕКТИВНОСТЬ ПРЕДВАРИТЕЛЬНОЙ ОБРАБОТКИ СЫРЬЯ ДЛЯ ПОВЫШЕНИЯ ВЫХОДА ПЕКТИНА
}

\section{PRE-PROCESSING EFFICIENCY RAW MATERIALS TO INCREASE PECTIN'S OUTPUT}

Санкт-Петербургский национальный исследовательский университет информационных технологий, механики и оптики

Аннотация. В статье рассмотрен более экологичный способ̆ производства пектина по сравнению с классической кислотной схемой, которая требует применения сильньх минеральных кислот и токсичных растворителей.

Материалы и методы, результаты и обсуждения. В выполненной работе не используются сильные минеральные кислоть, что должно вызывать падение выхода конечного продукта, однако сделань попьтки найти методы, устраняюшие эти препятствия и повысить выход конечного продукта. Исследована возможность увеличения выхода пектина, полученного с помощью кислотного гидролиза с использованием лимониой кислоты, за счет применения предварительного СВЧ-воздействия на иитрусовое сырьё. Цель исследования состояла в оиенке влияния СВЧ-обработки на стадии подготовки сырья-суики и экспериментальном подборе параметров суики с сохранением высоких качественных показателей получаемого пектина. Внимание уделено получению высокоэтерифицированного пектина, которьй иироко используется в пищевой промьшиенности в качестве студнеобразователя и загустителя. При производстве пектина возможно использовать вторсырье. Такая переработка отходов не только экономически снижает расходы производства, но и улучиает экологическую ситуачию утилизачии отходов. Для производства пектина возиожно использовать отходы соковой промынилениости.

В качестве сырья в исследовании использовались флаведо и альбедо апельсинов, сорт которых лидирует в мире по количеству использования при производстве соковой продукиии. Для получения пектина в данной работе использовался кислотный метод. Гидролиз проводился с использованием лимонной кислоть в три стадии. Осаждение проводилось этиловыл спиртом. Подготовка пектиносодержацеего сырья способна в значительной мере повлиять на качество получаемого пектина. В настоящее время для хранения и подготовки к переработке вторичного пищевого сьгрья главньм образом используют конвективную суику. Произведена оченка влияния различных видов суики иитрусового сьрья, применяемого для производства пектина. Сравниваются качественные и количественные показатели получениого пектина, такие как степень этерификации, молекулярная масса, студнеобразование и выход, для сырья, высуиенного конвективным методом и комбипированным методом, сочетающим предварительнуо СВЧ-обработку и обдувку сухим воздухом. Представлень кривые сравниваемьхх методов предварительной суики. Проанализирована скорость выхода пектина по стадиям гидролиза в зависимости от рассматриваемых методов суики. Подобраны оптимальные мощностные режимы для предварительной СВЧсуики цитрусового сырьл. Рассмотренньй способ получения пектина с использованием СВЧ-обработки сырья позволяет при сохранении качественньх показателей упростить пехнологию, повысить выход и сократить не только время суики, но и продолжительность гидролиза.

Заключение. Полученные данные представляют иенность для разработки или усовериенствования технологии промыиленного метода произодства пектина, использующего экологические способы экстракиии без применения сильных минеральных кислот, для увеличения выхода и качества пектина.

Ключевые слова: пектин, экологичный метод, СВЧ, конвективная сушка, лимонная кислота, кривая сушки.

Abstracts. The article discusses a more environmentally friendly method of pectin production compared to the classic acid scheme, which requires the use of strong mineral acids and toxic solvents.

Materials and methods, results and discussions. In the work performed, strong mineral acids are not used, which should cause a drop in the yield of the final product, however, attempts have been made to find methods that eliminate these obstacles and increase the yield of the final product. The possibility of increasing the yield of pectin obtained by acid hydrolysis with the use of citric acid through the use of preliminary microwave exposure to citrus raw materials has been investigated. The purpose of the study was to assess the effect of microwave treatment at the stage of raw material preparation - drying and experimental selection of drying parameters while maintaining high quality indicators of the obtained pectin. Attention is paid to obtaining highly esterified pectin, which is widely used in the food industry as a gelling agent and thickener. It is possible to use recyclable materials in the production of pectin. Such waste processing not only economically reduces production costs, but also improves the environmental situation of waste disposal. For the production of pectin, it is possible to use waste from the juice industry. As raw materials in the study, we used the oranges flavedo and albedo, the variety of which is the world's leader in the number of uses in the production of juice products. To obtain pectin, the acid method was used in this work. The hydrolysis was carried out using citric acid in three stages. Precipitation was carried out with ethyl alcohol. The preparation of pectin-containing raw materials can significantly affect the quality of the pectin obtained. Currently, convective drying is mainly used for storage and preparation for processing of secondary food raw materials. An assessment of the influence of various types of drying of citrus raw materials used for the production of pectin has been made. The qualitative and quantitative indicators of the obtained pectin, such as the degree of esterification, molecular weight, gelation and yield, are compared for raw materials dried by the convection method and the combined method combining 
microwave pretreatment and dry air blowing. The curves of the compared predrying methods are presented. The rate of release of pectin by stages of hydrolysis is analyzed depending on the considered drying methods. The optimal power modes for preliminary microwave drying of citrus raw materials have been selected.

Conclusion. The considered method of obtaining pectin using microwave processing of raw materials allows, while maintaining quality indicators, to simplify the technology, increase the yield and reduce not only the drying time, but also the duration of hydrolysis. The data obtained are valuable for the development or improvement of the technology of an industrial method for the production of pectin, using ecological methods of extraction without the use of strong mineral acids, to increase the yield and quality of pectin.

Key words: pectin, environmentally friendly method, microwave, convective drying, citric acid, drying curve.

Introduction. At the present time, serious problems have arisen related to the increased environmentally unfavorable load on the environment. Much attention is paid to waste processing. This is especially true in the food industry, where waste can potentially be converted into more valuable products or raw materials for other industries.

During industrial production of orange juice, $40-60 \%$ of the orange is considered waste [1]. This waste can be the raw material for the production of essential oils, flavonoids, pectin, and other important foods.

Convection drying is mainly used for storage and preparation for processing of secondary food raw materials. In the process of drying, there is a chemical transformation of the components of pectin-containing raw materials, which can significantly affect the quality of the pectin obtained [2]. During storage, it is subject to enzymatic, biochemical and microbiological changes that lead to rapid deterioration. Thus, drying of raw materials is a necessary step in the production of pectin. Although convective drying does not always have a beneficial effect on the quality of the pectin obtained, at present, due to its simplicity and economy, it is the main method for preserving pectin-containing raw materials.

Since the beginning of the XXI century, studies of Russian and foreign scientists began to appear related to the use of microwave drying for the needs of the food industry, since this type of drying involves a significantly shorter drying time for Pekin-containing raw materials. And it's not only about saving time, but also about a different way of supplying heat to the material, which can presumably affect the quality and quantity of the final product.

On the other hand, the production of pectin is associated with the use of harmful and hazardous components, such as strong acids, alkalis and toxic solvents such as acetone, methanol, etc. Due to the large amount of hazardous waste, not every enterprise can afford the classic technology of pectin production [6]. Recently, in the development of pectin production technology, it is possible to identify a trend towards the development of environmentally friendly production methods [7].

In the work performed, strong mineral acids are not used, which should cause a drop in the yield of the final product, however, attempts have been made to find methods that eliminate these obstacles and increase the yield of pectin.

The aim of the study was to assess the effect of raw material pretreatment due to microwave exposure on the pectin yield and to select the parameters of this effect.

Materials and methods. For the purposes of the study, we used a Valencia orange. This variety is the world's leader in the number of uses in the production of juice products. Since it is advisable to consider the possibility of using industrial waste to obtain pectin, the peel of the Valencia variety is considered the most relevant raw material.

The flavedo and albedo of the fruit were removed by hand and minced.

Raw materials were analyzed for moisture content by gravimetric method. For this, three samples were taken from the mixed raw materials.

The moisture content of raw materials was determined by the formula:

$$
\omega=\frac{m_{1}-m_{2}}{m_{1}} \cdot 100 \%
$$

where $\mathrm{m}_{1}$ - sample weight before drying, $\mathrm{g}$

$\mathrm{m}_{1}$ - sample weight after drying, $\mathrm{g}$.

Three samples of equal mass for drying in microwave and three samples for convective drying were isolated from the total amount. The mass of each sample is $100 \mathrm{~g}$.

Part of the fresh raw material was dried using convective drying, the other part - using microwave drying, and the third part - using the combined method.

Drying was carried out to a final moisture content of the product of $10 \%$. The moisture content of the dry product was determined by the gravimetric method, similar to that described above.

Convective drying was carried out in a drying oven at a temperature of $70^{\circ} \mathrm{C}$.

Microwave drying was carried out in a household microwave oven at different powers.

Combined drying consisted of an alternation of microwave exposure for 5 minutes with a 5 -minute period of blowing dry air.

Samples weighing $15 \mathrm{~g}$ were taken from each type of dry raw material and sent for hydrolysis.

The raw materials were washed in cold water $\left(10^{\circ} \mathrm{C}\right)$ to remove water-soluble impurities.

Grinding was carried out in a screw grinder providing a particle size of less than $1 \mathrm{~mm}$. The raw materials were mixed. 
The acid method was used to obtain pectin. Hydrolysis was carried out using citric acid to achieve a $\mathrm{pH}$ value of 2.5 at a temperature of $70^{\circ} \mathrm{C}$, hydromodule $1: 10$. The hydrolysis was carried out in three stages, each stage lasted 60 minutes. The total hydrolysis time is 180 minutes.

Evaporation of pectin was carried out on a rotary evaporator with continuous stirring, $\mathrm{t}=70^{\circ} \mathrm{C}, \mathrm{P}=60 \mathrm{mbar}$.

Precipitation was carried out with $96 \%$ ethyl alcohol. The precipitate was separated by filtration on a Buchner funnel and washed with alcohol.

The resulting pectin was dried in an oven at a temperature of $50^{\circ} \mathrm{C}$.

Pectin is divided into highly esterified, low esterified and low esterified amidated. Each type of pectin is used for its own purposes under different conditions. The highest gelatinous ability is possessed by highly esterified pectin with a degree of esterification of more than $50 \%$.

The degree of esterification of the obtained pectin was determined by the titrometric method according to GOST 29186-91. Pectin. Technical conditions.

The molecular weight was determined by a viscometric method using a VPZh-1 capillary glass viscometer.

The molecular weight was found using the Kuhn-Mark-Huwink formula:

$$
[\eta]=k \cdot M^{a} \text {, }
$$

where $[\eta]$ - absolute viscosity of the solution,

$\mathrm{M}$ - molecular weight

$\mathrm{k}, \mathrm{a}$ - coefficients depending on temperature and polymer-solvent system, here we take $\mathrm{k}=1,1 \cdot 10^{-5}, \mathrm{a}=1,22[2]$.

Gelling was determined organoleptically. For this analysis, jellies were prepared according to GOST $29186-91$. Pectin. Technical conditions.

Results and discussion. After preliminary selection at processing plants, the moisture content of fresh raw materials was $77 \%$.

The raw material was crushed and dried in batches of $100 \mathrm{~g}$ on a silicone substrate. Average particle size $7 \times 5 \times 2 \mathrm{~mm}$. For uniform heating, this is especially important for microwave exposure, it is necessary that the linear dimension in at least one direction does not exceed 2-5 $\mathrm{mm} \mathrm{[5 \} .}$

When selecting the power, the recommendations of other authors on the critical influence of high temperatures during drying of raw materials on the quality of pectin were taken into account. In the case of drying raw materials using the microwave method without interruptions for blowing, the temperature of the raw materials reached $94{ }^{\circ} \mathrm{C}$, which negatively affects the properties of the final product. In many works it is indicated that the temperature should not exceed $70-80^{\circ} \mathrm{C}[2]$.

The literature describes a method of combined drying with alternating five-minute microwave exposure with a five-minute air blow [3]. This method does not take into account the change in moisture content of the product during drying. There is an increase in temperature at the beginning of the heating of raw materials and a drop in temperature as the humidity decreases.

The optimal power value for microwave drying was determined, equal to $300 \mathrm{~W}$. At a higher power $(450 \mathrm{~W}$ or more), the product began to burn, a lower value (180 W or less) unjustifiably lengthened the drying time.

Drying was carried out with alternating microwave exposure with air blowing. One cycle consisted of 2-4 minutes' exposure to microwave and 4-minute air blowing. This method makes it possible to take full advantage of the main advantage of microwave heating - high speed and to avoid uneven heating of individual sections of the processed raw materials, since during cyclic heating it is possible to redistribute temperatures by thermal conductivity of the material. Table 1 shows the average temperature on the surface of the raw material, measured at five points eight times for each cycle. At the beginning of drying, with a large amount of free moisture, the energy of the microwave field is spent mainly on the evaporation of moisture and partially on the compensation of heat into the environment, then the bound moisture begins to evaporate, as well as endothermic processes associated with the chemical transformation of proteins, carbohydrates and the destruction of the tissue of raw materials. ...

Table 1

Scheme of the combined drying method with alternating microwave energy supply and air blowing

\begin{tabular}{|c|c|c|c|c|}
\hline Cycle number & Drying time, minutes & Duration, minutes & Impact & Average temperature, K \\
\hline \multirow{2}{*}{1} & $1-4$ & 4 & Microwave & 333 \\
\cline { 2 - 5 } & $5-8$ & 4 & Blowing & 323 \\
\hline \multirow{2}{*}{2} & $9-12$ & 4 & Microwave & 341 \\
\cline { 2 - 5 } & $13-16$ & 4 & Blowing & 318 \\
\hline \multirow{2}{*}{3} & $17-20$ & 4 & Microwave & 343 \\
\cline { 2 - 5 } & $21-24$ & 4 & Microwave & 340 \\
\hline \multirow{2}{*}{4} & $25-28$ & 4 & Blowing & 315 \\
\cline { 2 - 5 } & $29-32$ & 4 & Bicrowave & 348 \\
\cline { 2 - 5 } & $33-34$ & 2 & Microwave & 317 \\
\cline { 2 - 5 } & $35-38$ & 4 & Blowing & 347 \\
\cline { 2 - 5 } & $39-40$ & 2 & Microwave & 317 \\
\hline \multirow{2}{*}{6} & $41-44$ & Blowing & 346 \\
\cline { 2 - 5 } & $45-46$ & 2 & Microwave & 318 \\
\hline
\end{tabular}




\begin{tabular}{|c|c|c|c|c|}
\hline & $53-56$ & 4 & Blowing & 319 \\
\hline \multirow{2}{*}{9} & $57-59$ & 3 & Microwave & 343 \\
\cline { 2 - 5 } & $60-63$ & 4 & Blowing & 316 \\
\hline \multirow{2}{*}{10} & $64-66$ & 3 & Microwave & 339 \\
\cline { 2 - 5 } & $67-70$ & 4 & Blowing & 317 \\
\hline
\end{tabular}

With a graphical representation of the results obtained in Figure 1, one can see a rise in temperature when the microwave energy is supplied and a decrease when the microwave energy is turned off. Ambient temperature $-27^{\circ} \mathrm{C}$. The average temperature inside the chamber at the time of microwave exposure is $46^{\circ} \mathrm{C}$. The average temperature on the sample surface first rises and then slowly falls. The averaged value shows that the maximum temperature falls on the sixth cycle.

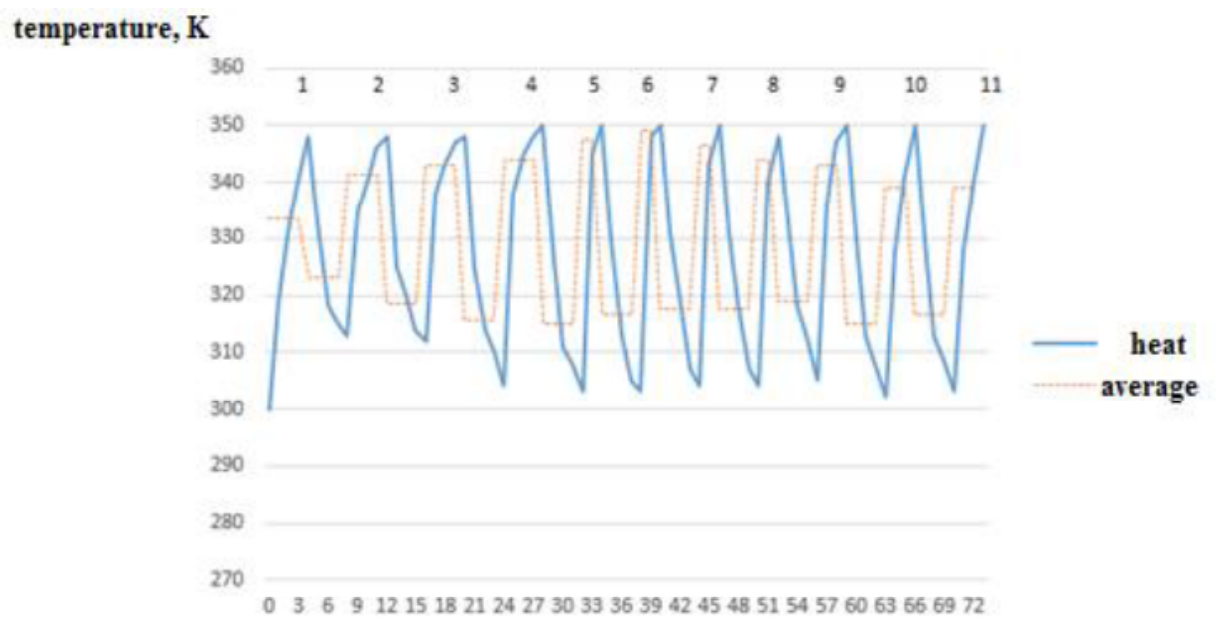

time, $\min$

Fig. 1. Change in temperature in the drying chamber with a combined method of drying citrus raw materials

After the fourth cycle, the temperature on the surface of the raw material rises to the limiting value of $77^{\circ} \mathrm{C}$, therefore, on the fifth cycle, it is necessary to reduce the exposure time to microwave. The peak point of the fourth cycle corresponds to a product moisture content of $40 \%$. The peak point of the sixth cycle corresponds to a moisture content of $33 \%$, which, as can be seen from the microwave drying curve (Figure 3), corresponds to the critical moisture content point. Up to the point of critical moisture content, mainly free moisture is removed, but the microwave effect also affects the bound moisture, which also affects the rise in temperatures. After this point, the drying rate decreases as the moisture content of the product decreases. During this period, the bound moisture is removed, and the gradual decrease in the drying rate is explained by the increase in the binding energy of moisture with the material. During this period, the process of removing moisture depends on the moisture content, the nature of the connection of moisture with the material, the physicochemical properties of the material. As the moisture content of the product decreases, the average temperature also decreases. It is assumed that due to the temperature distribution in the center of the sample, the temperature constantly increases during the entire drying time.

With the described drying method, the threshold of $70^{\circ} \mathrm{C}$ was exceeded. However, the duration of high temperatures was short (no more than 7 minutes) and this did not significantly affect the quality of the pectin obtained. Temperature distribution over the entire drying time is shown in Figure 2.

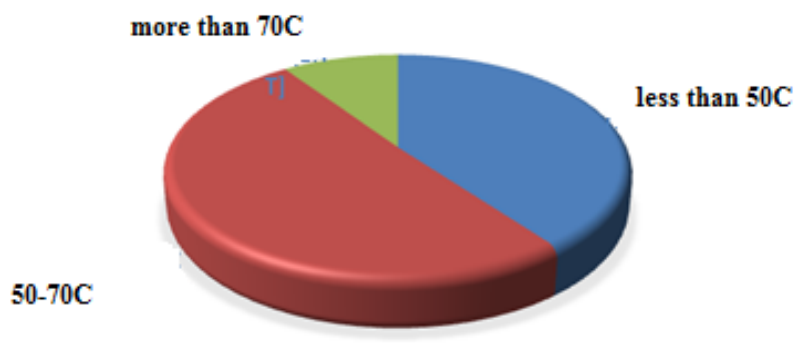

Fig. 2. Temperature analysis

Analysis of the diagram shows that microwave treatment significantly reduces drying time. For $100 \mathrm{~g}$ of raw materials, moisture $77 \%$, using microwave, it took 73 minutes to dry the product to a final moisture content of $10 \%$, while convective drying took 350 minutes.

The drying curves are shown in Figure 3. 


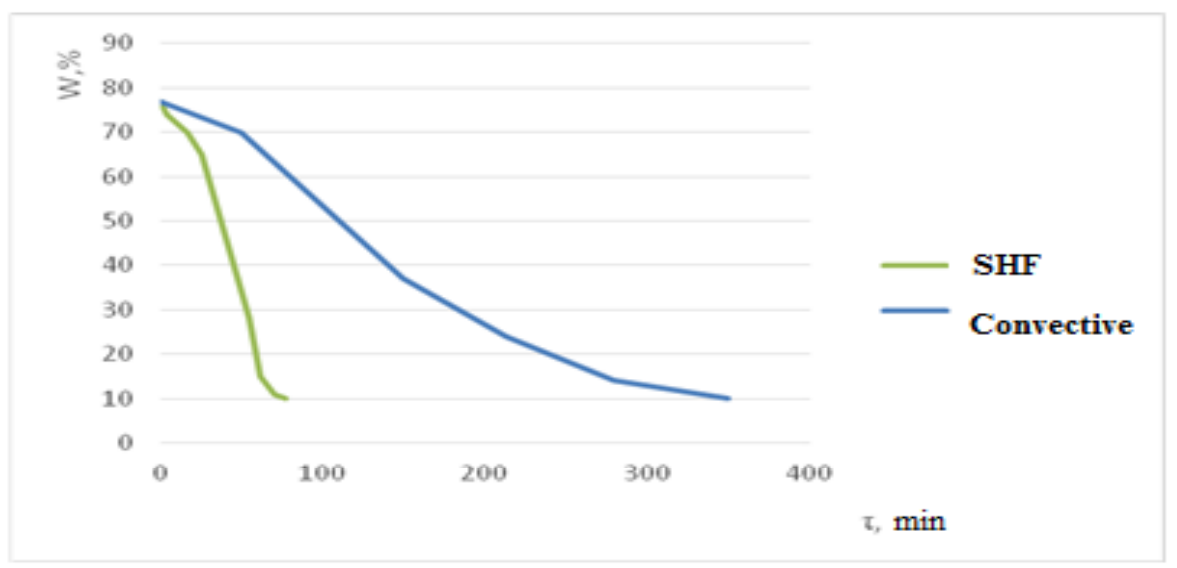

Fig. 3. Drying curve

Organoleptically dried samples did not differ from each other.

Pre-dried raw materials were subjected to extraction. For the extraction of pectin, the same methods were used for all samples. In the work performed, the use of strong mineral acids was abandoned in favor of citric acid. The extraction was carried out in three stages. After each stage, the aqueous solution was decanted and the raw material was poured with a new portion of the acidic solution. The output of pectin by stages is shown in Figure 2 . It shows that the hydrolysis of raw materials dried using microwave is faster. After the second stage, it was already possible to obtain $90 \%$ of the pectin from the total pectin obtained. The raw material, convectively dried after the second stage, gave only $60 \%$ yield. Thus, to obtain pectin by the described method, two hydrolysis stages can be used, which will shorten the extraction time in general.

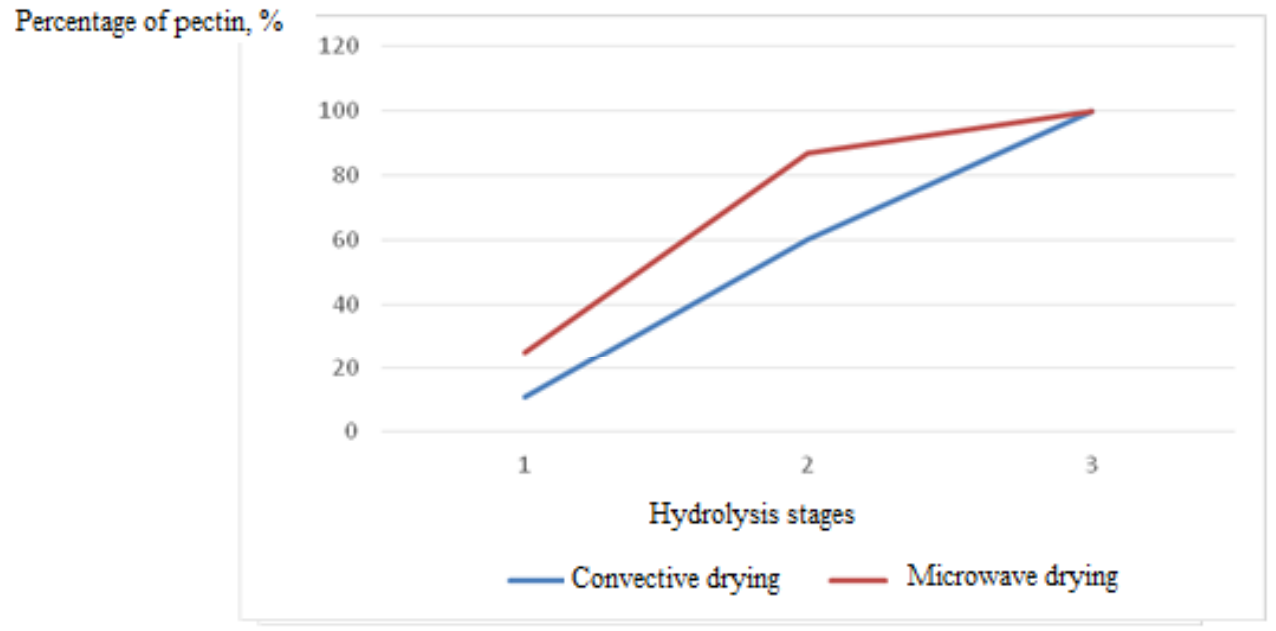

Fig. 4. The output of pectin by stages of hydrolysis

The total yield of pectin from raw materials after microwave processing of raw materials is 2.1 times higher than after convective drying.

Apparently, this can be explained by the effect of microwave energy on the raw material when heated. Orange peel has a capillary-porous structure and is a complex substance in which the components have different dielectric properties. The main role in the process of energy absorption during dielectric heating of a material is played by water molecules, which are dipoles. When an electric field is applied to a dipole molecule, its polarization occurs, caused by the attraction of negative and positive charges of the molecules in accordance with the direction of the external electric field, which subsequently under the action of an alternating field come into oscillatory motion. When exposed to an alternating electromagnetic field, the raw material, which is a dielectric material, heats up due to dielectric losses, that is, the field energy is converted into heat.

Due to its high dielectric constant, water absorbs most of the radiation, heats up and begins to evaporate. Since the water in the raw material is in a confined space, then with the beginning of its boiling, excess pressure is created. The increasing internal pressure significantly deforms the structure of the product throughout the entire volume of the material. Microwave treatment makes it possible to disrupt the continuity of the cell membranes of plant materials prior to extraction. 
The structure of the raw material acquires a developed contact surface of the phases, which accelerates the mass exchange processes and at the same time ensures the uniform passage of hydrolysis of protopectin substances, regardless of their localization in the cell. As a result, the process of hydrolysis of protopectin substances is completed faster than for raw materials obtained by convective drying, which significantly increases the yield of pectin.

Moisture during microwave processing of raw materials evaporates faster, which increases the drying rate, and the cell walls containing pectin heat up less, which improves its quality.

The obtained samples can be classified as highly esterified, since the degree of esterification of all samples was more than $50 \%$.

Molecular weight and gelation did not differ significantly between samples. For the formation of jelly $150^{\circ}$ $\mathrm{SAG}$, a mass of $70 \mathrm{kDa}$ is sufficient [8]. All samples have an average molar mass greater than this value.

The experimental results are shown in Table 2.

Table 2

Experimental results for different methods of raw material preparation

\begin{tabular}{|l|c|c|}
\hline & Convection Drying & Combined Drying \\
\hline Pectin output to dry matter, $\%$ & 10,8 & 21,9 \\
\hline Esterification degree, $\%$ & 75 & 76,5 \\
\hline Average molecular weight, $\mathrm{kDa}$ & 103 & 96 \\
\hline
\end{tabular}

Conclusions. The paper describes a method of combined drying with a cyclic supply of microwave energy. The optimal power of microwave exposure is determined, equal to $300 \mathrm{~W}$. The point of critical moisture content was found, on the basis of which the cycle duration was selected.

A comparison was made between microwave drying and convective drying of citrus raw materials, which were used to obtain pectin. Drying curves are given.

There was no significant difference in the quality of the pectin obtained. At the same time, microwave drying made it possible to reduce the drying time by 4.5 times and to increase the output of pectin by 2.1 times.

The method of obtaining pectin using microwave drying allows to simplify the technology, increase the yield and reduce not only the drying time, but also the duration of hydrolysis.

\section{ЛИТЕРАТУРА}

1. Licandro G. Odio CE. Citrus by-products. London: Taylor \& Francis. Citrus. - 2002. - pp 159-170.

2. Донченко Л. В., Фирсов Г. Г. Пектин: основныс свойства, производство и применение. М. : ДеЛи принт. - 2007. $-275 \mathrm{c}$.

3. Пат. 2198183 Российская Федерация, МПК7 С08B37/06, А23L1/0524. Способ получения пектина / Ильина И.А., Земскова З.Г., Уврачева Т.В., Квасенков О.И.; заявитель и патентообладатель Кубанский государственный технологический университет. - № 2000128132/04; заявл. 13.11.2000; опубл. 10.02.2003.

4. Перфилова О.В. Изменение биологической активной ценности вторичного сырья в процессе СВЧ-нагрева // Вестник красноярского государственного аграрного университета. - 2018. - № 2(137). - С. 123-128.

5. Рогов И.А., Некрутман С.В. Сверхвысокочастотный и инфракрасный нагрев пищевых продуктов. М.: Пищевая промышленность. $-1976 .-212 \mathrm{c}$

6. Pigliaro M., Cirimin and others. Pectin Production and Global Market./ Agro Food Industry Hi Tech. India. 2016. 27(5). - pp. 17-20.

7. Eun-Hi Cho Ho-Tak Jung Byung-Hoo Lee Green process development for apple-peel pectin production by organic acid extraction// Carbohydrate Polymers - 2019 - 204 - pp. 97-103.

8. Тры А.В., Михеева Л.А. Влияние различных факторов на выход пектиновых веществ, выделенных из растительного сырья.// Научные ведомости. Серия Естественные науки. - 2014. - №23(194). С.123-128.

9. Кукин М.Ю. Усоверпенствование технологии получения пектина из яблок.// Научный журнал НИУ ИТМО. Серия «Процессы и аппараты пищевых производств». - 2017. - №2(32). - С. 9-17.

\section{REFERENCES}

1. Licandro G. Odio CE. Citrus by-products. London: Taylor \&amp; Francis. Citrus. - 2002. - pp 159-170.

2. Donchenko L. V., Firsov G. G. Pektin: osnovnye svoistva, proizvodstvo i primenenie. M. : DELi print. - 2007. - 275 s.

3. Pat. 2198183 Rossiiskaya Federatsiya, MPK7 S08V37/06, A23L1/0524. Sposob polucheniya pektina / Il'ina I.A., Zemskova Z.G., Uvracheva T.V., Kvasenkov O.I.; zayavitel' i patentoobladatel' Kubanskii gosudarstvennyi tekhnologicheskii universitet.

№ 2000128132/04; zavavl. 13.11.2000; opubl. 10.02.2003

4. Perfilova O.V. Izmenenie biologicheskoi aktivnoi tsennosti vtorichnogo syr'ya v protsesse SVCh-nagreva // Vestnik krasnoyarskogo gosudarstvennogo agrarnogo universiteta. - 2018. - № 2(137). - S. 123-128.

5. Rogov I.A., Nekrutman S.V. Sverkhvysokochastotnyi i infrakrasnyi nagrev pishchevykh produktov. M.: Pishchevaya promyshlennost'. - 1976. $-212 \mathrm{~s}$.

6. Pigliaro M., Sirimin and others. Pectin Production and Global Market.// Agro Food Industry Hi Tech. India. 2016. 27(5). - pp. 17-20.

7. Eun-Hi Cho Ho-Tak Jung Byung-Hoo Lee Green process development for apple-peel pectin production by organic acid extraction// Carbohydrate Polymers - 2019 - 204 - pp. 97-103.

8. Try A.V., Mikheeva L.A. Vliyanie razlichnykh faktorov na vykhod pektinovykh veshchestv, vydelennykh iz rastitel'nogo syr'ya.// Nauchnye vedomosti. Seriya Estestvennye nauki. - 2014. - №23(194). S.123-128. 
9. Kukin M.Yu. Usovershenstvovanie tekhnologii polucheniya pektina iz yablok.// Nauchnyi zhurnal NIU ITMO. Seriya «Protsessy i apparaty pishehevykh proizvodstV». - 2017. - №2(32). - S. 9-17.

\section{OБ ABTOPAX | ABOUT AUTHORS}

Алексеев Геннадий Валентинович, доктор технических наук, профессор факультета биотехнологии, Национального исследовательского университета ИТМО, 191003, Санкт-Петербург, ул. Ломоносова, 9 , +7(921)335-07-96, gva203@mail.ru

Alekseev Gennady Valentinovich, Doctor of Technical Sciences, Professor of the Faculty of Biotechnology, National Research University ITMO, 191003, St. Petersburg, Lomonosov St., 9,

+7 (921)335-07-96,gva203@mail.ru

Егорова О.льга Алксеевна, аспирант, факультета бнотехнологии, Национального исследовательского университета ИТМО, 191003, Санкт-Петербург, ул. Ломоносова, 9, +7(921)335-07-96, jeerol@list.ru Egorova Olga Alkseevna, PhD student, Faculty of Biotechnology, National Research University ITMO, 191003, St. Petersburg, Lomonosova St., 9, +7 (921) 335-07-96, jeerol@list.ru

Леу Анна Геннадьевна, аспирант, факультета биотехнологии, Национального исследовательского университета ИТМО, 191003, Санкт-Петербург, ул. Ломоносова, 9, +7(921)335-07-96, leu1968@msil.ru Leu Anna Gennadievna, PhD student, Faculty of Biotechnology, National Research University ITMO, 191003, Saint Petersburg, Lomonosov st., 9, +7 (921) 335-07-96, leu1968@msil.ru 